\title{
FREIGHT FORWARDING COMPANY: THE EFFECT OF SERVICE FAILURE, RECOVERY, SATISFACTION, AND CUSTOMER LOYALTY
}

\author{
Adi Yudi', Endang Ruswanti ${ }^{*}$ \\ 'Faculty of Economics and Business, Esa Unggul University \\ Address: ' Jl. Arjuna Utara No. 9, Kebon Jeruk, Jakarta, Indonesia 11510 \\ *Email : endang.ruswanti@esaunggul.ac.id
}

\begin{abstract}
This study will examine the relationship between the impact of service failure and service recovery on customer satisfaction and loyalty. The research objective was to determine the effect of service failure can be up to customer loyalty. The object of this research is customers who use expedition services located in Jakarta. This research method uses quantitative methods using a questionnaire measuring instrument. The sampling technique used is simple random sampling. To analyze the data using SEM (Structural Equation Modeling) analysis tools with Lisrel. The results of this study conclude that, first, service failure affects service recovery. Secondly, service recovery affects customer loyalty. Third, service recovery affects customer satisfaction, and the last fourth of customer satisfaction also affects customer loyalty.
\end{abstract}

Keywords: Service Failure, service recovery, customer satisfaction, customer loyalty

JEL Classification: $\mathrm{G} 14$

Article History:

Received: June 2, 2021; Revised: August 6, 2021; Accepted: August 9, 2021; Available Online : August 28, 2021 DOI: $10.20473 / \mathrm{jm} t \mathrm{t} . \mathrm{v} 14 \mathrm{i} 2.27223$

\section{INTRODUCTION}

The main business strategy in service marketing and management activities is to retain customers and increase customer satisfaction (Dawi et al., 2018). Technological development in the digital era is currently growing and bringing in many new competitors in freight forwarding services. One of the service companies is a company that is engaged in providing goods delivery service. Thus, the service company must focus on customer satisfaction and pay more attention to the complaints from customers because the role of customers is very important for the company to achieve success of the service company. A service company cannot avoid service failure. If it is not handled correctly, it can result in negative things for the company, which will lead to customer dissatisfaction (Hua, 2012). Therefore, service companies must avoid losing customers to remain profitable and learn to be better at responding to service failure properly (Matikiti et al., 2018). The service recovery efforts are the most effective way to ensure customers meet the desired expectations (Pai et al., 2019). Through service recovery, there will be potential to create more goodwill from consumers if another mistake occurs (Palich et al., 2000). The improvement of service quality 


\section{Adi Yudi \\ Endang Ruswanti}

is related to customer loyalty. Thus, if there is a development in the service received by customers, it will impact customer loyalty (Nurlitasari and Syah, 2016). Loyal customers will be the main strength of the relationship between buying behavior and the customer's personal relationship with the company (Boo, 2017)

Based on Keiningham et al. (2014), it was found that customer satisfaction has a positive influence on Service failures that do not result in physical damage. The example does not typically address the severity of service failures, like those that result in injury or death to the Airline Industry. Matikiti et al. (2018) also found that service failure has a positive effect on service recovery. Research from Christina et al. (2019) also found a positive influence on the relationship between fairness in service recovery and customer loyalty. Cheng et al. (2008) suggested that the relationship between customer satisfaction and strong customer loyalty can prevent customers from moving to other competitors. Many researchers have supported the idea that customer satisfaction is a determinant that affects customer loyalty (Loureiro, 2010). Currently, many people view that service failure will further decrease the service provided to customers. However, from the beginning of the emergence of service failures, it can be the initial process of learning to correct all mistakes to customers and provide the best service to customers to loyalty. So the novelty of this research can consider the relationship of service failure, customer recovery, customer satisfaction, and customer loyalty, whether it has a strong relationship between each other or weakening of all these variables. In addition, previous studies have mainly researched airlines and restaurants Keiningham et al. (2014). In comparison, this research was conducted on freight forwarding companies. This study aimed to determine the effect of service failure on service recovery, service recovery on customer loyalty, service recovery on customer satisfaction, and the influence of customer satisfaction on customer loyalty.

\section{LITERATURE REVIEW AND HYPOTHESES}

\section{Relationship between Service Failure and Service Recovery}

The severity of service failure has been described by Lai and Chou (2015) as the way customers view the service failure magnitude, if the service failure occurs more frequently, customers will feel a large loss. Keiningham et al. (2014) found that the severity of service failure had a significant positive impact on recovery expectations in the airline industry. Service failure can occur when customers have negative feelings, are not satisfied, or have an unpleasant experience when being served (Pugh, 2001).

The severity of service failure has been described by Lai and Chou. (2015) as the way customers perceive the magnitude of service failures that have occurred. If the service failure is more intense, the customer would feel a significant loss (Liaw et al., 2012). 
Keiningham et al. (2014) found that the severity of service failure had a negative impact on service recovery expectations in industrial airlines. Service recovery can occur from what has been done by a service provider in response to service failure (Weun et al., 2004). Service failure has a negative impact on satisfaction and customer service recovery (Santos and Boote, 2003). Thus, the research of Smith and Bolton (2002) stated that the important role of service recovery could consistently achieve satisfaction in a service failure situation. Thus, the hypothesis that can be formulated is as follows:

\section{$H_{1}$ : Service failure has an effect on service recovery.}

\section{Relationship between Service Recovery and Customer Loyalty}

After a service failure, customers often expect the service provider to consider steps to ensure service recovery (Pai et al., 2019). Keiningham et al. (2014) found that the severity of service failure significantly impacted recovery expectations in industrial companies. Seon Hee. (2016) also found a significant relationship between failure severity level and service recovery. Sarkar Sengupta et al. (2015) proposed that recovery measures for service failure would positively affect customer behavior, strengthen the relationship between the customer and the company, and increase customer loyalty; on the contrary, improper service recovery will increase customer dissatisfaction.

Service recovery is required to restore customer loyalty from service failure (Fan et al., 2015). Service recovery is the action of the service provider to resolve customer service failure complaints (Dong et al., 2008). Service recovery aims to turn customer dissatisfaction into a satisfied condition that can build company relationships with customers (Pai, Ko and Santos, 2019). From the literature above, the proposed hypothesis is as follows:

\section{$\mathrm{H}_{2}$ : Service recovery has an effect on customer loyalty.}

\section{Relationship between Service Recovery and Customer Satisfaction}

Customer satisfaction is an overall or global customer assessment of the extent to which service performance is in line with expectations (Anderson and Sullivan, 1993). Customer satisfaction can be described as a process. Currently, the most widely adopted process theory is "expectancy-disconfirmation," in which satisfaction can be viewed as exceeding customer expectations (Johnston, 2007). Researchers have also proven that there is positive satisfaction associated with disconfirmation (Loureiro, 2010).

In other words, customers receive more benefits than they expect. A transformation, their experience is greater than the level of satisfaction. The service recovery literature shows that the disconfirmation of this model is appropriate in the service recovery situation, which shows that customer satisfaction with service failure and recovery has an effect on service 
Adi Yudi

\section{Endang Ruswanti}

satisfaction (Boshoff, 1997; Spreng and Page (2003). Based on the research of Christina et al. (2019), when a customer experienced a service failure, the level of satisfaction would be higher after service recovery attempts were made than in a situation with no service failure occurred.

From the above literature, the hypothesis that is proposed is as follows:

\section{$\mathrm{H}_{3}$ : Service recovery has an effect on customer satisfaction.}

\section{Relationship between Customer Satisfaction and Customer Loyalty}

The fairness perceived by the customer can affect the level of customer satisfaction on the service recovery strategy (Kau and Loh, 2006). Service recovery serves as a key factor in obtaining customer satisfaction, increasing customer loyalty (Ajami et al., 2018). Research by Mccollough et al. (2000) shows that higher recovery performance will increase satisfaction support for service recovery.

Failure to perform a service can cause dissatisfaction on customers when the service is not repaired or restored (Andreassen, 2000). Thus, based on the result of the research conducted by Terry Kim et al. (2009), satisfaction and service recovery positively affect customer relationship variables, such as; trust, WOM (Word of Mouth), and intention to revisit. From the above discussion, the following hypothesis is obtained:

\section{$\mathrm{H}_{4}$ : Customer satisfaction has an effect on customer loyalty.}

Based on the theoretical framework above, thus the research model can be described in Figure 1 below:

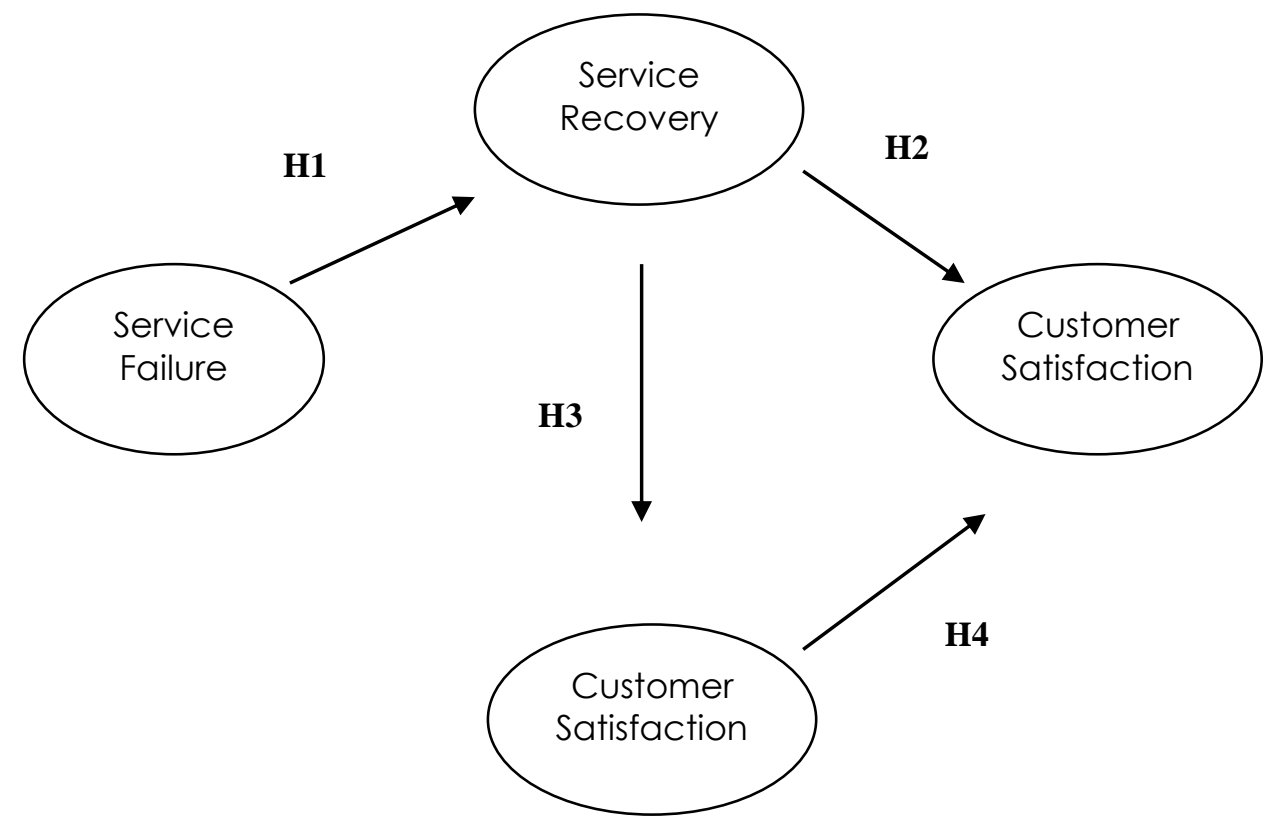

Figure 1. Conceptual Model 


\section{Jurnal Manajemen Teori dan Terapan \\ Volume 14. No. 2, Agustus 2021}

\section{RESEARCH METHODS}

Based on this research, we chose a location for companies engaged in the freight forwarding service sector in DKI (Special Capital Region of) Jakarta. Those are JNE, Sicepat, Anteraja, JNT companies. Those freight forwarding companies were chosen because they are some of the most developed companies in the freight forwarding service sector and are still widely used by their customers. The sampling technique used in this research was the simple random sampling technique because the sampling of members of the population was carried out randomly without looking at the strata in the population (Levy and Lemeshow, 2008). The population of this research is to distribute questionnaires online with google form to consumers who have used the freight forwarding service of PT Jalur Nugraha Ekakurir (JNE), PT Global Jet Ekspres (JandT Express), PT Tri Adi Bersama (Antaraja), PT Sicepat Ekspres (SiCepat) that located in Jakarta.

This research used a quantitative approach with secondary data because collection from the questionnaire survey method. The time of this research in data collection was carried out in November 2020 for 30 days by distributing questionnaires to respondents to fill out the questionnaire via a google form. In measuring the research instrument, this research used a Likert scale, consisting of 4 alternative answers, as follows: strongly disagree (SD); disagree (D); agree (A), strongly agree (SA) (Brenneman, 2005).

The instrument used in measuring service failure is based on instruments from Nikbin et al. (2012), which includes four questions with the Stability indicator and its operational definition. It is a strategy that emphasizes the increase or absence of service problems. Controllability and its operational definition is an important role that can control and provide feedback.

The instrument used in measuring service recovery is based on Boulding et al. (1993), which includes 15 questions with the Customer-Directed Extra-Role Behavior indicator. Its operational definition is the extra behavior aimed at customers, distributive justice. Its operational definition is a decision taken with the service provided, interactional justice, and its operational definition is procedural justice.

The instrument used in measuring customer satisfaction is based on Li-hua (2012), which includes seven questions with the decision to choose an indicator and its operational definition is the decision to choose Overall satisfaction. Its operational definition is the overall satisfaction, or in general, it is making the right decision, and its operational definition is to make the right decision. 


\section{Adi Yudi \\ Endang Ruswanti}

The last instrument used in measuring customer loyalty as an endogenous variable refers to the instrument developed by Lin and Ding (2007), which includes six questions with the Word of mouth (WOM) indicator. Its operational definition is a word of mouth delivery, switching behavior, and its operational definition is a shifting behavior.

Before being used in actual research, the questionnaire instrument was tested on 30 respondents outside the population from the actual research sample. This trial was conducted to find out which instrument was made with good results because an instrument would affect the correctness level of the data. The value of validity and reliability can show whether the instrument is good or bad (Brenneman, 2005). Thus, whether or not this instrument is suitable for the research on customers who use freight forwarding service in Jakarta could be seen. The result of the validity and reliability test of the 32 questions is as follows, 28 questions are declared as valid and reliable with Kaiser-Meyer-Olkin (KMO) $>0.500$ and Cronbach's Alpha value of 0.600 .

The validity test results for the statement of service failure, service recovery, and customer loyalty variables were all declared valid, provided that the value of KMO and MSA (antiimage correlation) $>0.500$ with 1 component matrix. Meanwhile, in the validity test of customer satisfaction, not all statements were valid, and that is in CS3 (0.714) with a component matrix of more than 1. In the reliability test, all statements of service failure, service recovery, customer satisfaction, and customer loyalty variables have been declared reliable with Cronbach's alpha $>0.6$, which shows good reliability (Brenneman, 2005). Thus, after analyzing the pre-test results of 30 respondents, the next step is to conduct a Structural Equation Model (SEM) test. According to (2014), the provision of the number of samples is five times the number of statements, and the number of samples in this study is 160 samples $(32 \times 5)$.

\section{RESULTS AND DISCUSSION}

The result of the research from 160 customer respondents who use freight forwarding service from PT Jalur Nugraha Ekakurir, from PT Jalur Nugraha Ekakurir (JNE), PT Global Jet Ekspres (JandT Express), PT Tri Adi Bersama (Antaraja), PT Sicepat Ekspres (SiCepat) in Jakarta shows that the majority of respondents are women by $54.38 \%$, age $26-35$ by $37.50 \%$, PT Jalur Nugraha Ekakurir service by $30 \%$. This shows that customers who use freight forwarding services are women age 26-35 years and the freight forwarding company from PT Jalur Nugraha Ekakurir.

The measurement results of the construct validity test in this research show that all are valid. All indicators in the variable service failure, service recovery, customer satisfaction, and 


\section{Jurnal Manajemen Teori dan Terapan \\ Volume 14. No. 2, Agustus 2021}

customer loyalty have a factor loading value with a good fit (>0.50). The t-value is greater from the t-table (1.96) with a significance level of $5 \%$. The construct reliability test meets the reliability requirements if the $C R$ (Construct Reliability) value is above 0.60 and the VE (Variance Extracted) value is above 0.50 (Hair et al. 2014). All the CR values meet the reliable requirements, including values greater than 0.60 , on the service failure variable $(0.94)$, service recovery (0.94), customer satisfaction (0.92), and customer loyalty (0.91). Likewise, all the VE values meet the reliable requirement $(>0.50),(0.80)$ for the service failure, $(0.81)$ for the service recovery, $(0.66)$ for customer satisfaction and customer loyalty at $(0.67)$.

The next step is to analyze the structural equation model by looking at the $\mathrm{R}^{2}$ value for each equation to find out how far the independent variables can manipulate the dependent variable. The first analysis, SR (Service Recovery), is influenced by SF (Service Failure) with an R2 of 0.78 . This means that $78 \%$ of the variants of SR (Service Recovery) can be explained from the SF (Service Failure) variable. The remaining $22 \%$ can be explained by other variables that are excluded in this research. The second analysis, CS (Customer satisfaction), is influenced by SR (Service Recovery) with $R^{2}$ of 0.79 . This means that $79 \%$ of the variants of CS (Customer satisfaction) can be explained by the SR (Service Recovery) variable. The remaining $21 \%$ can be explained by other variables excluded in this research. The third analysis is that LC (Customer Loyalty) is influenced jointly by SR (Service Recovery) and CS (Customer satisfaction) with R2 of 0.91 . This means that $91 \%$ of the variants of LC (Customer Loyalty) can be explained by the SR (Service Recovery) and CS (Customer satisfaction) variables. Other variables can explain the remaining $9 \%$ that are excluded in this research.

The goodness of fit test for all models consists of several SEM criteria that can be used. Based on the analysis of groups 1 to 7 of this research, almost all test results have a good fit, including Chi-Square, ECVI, AIC and CAIC, and Fit Index. The obtained results show close fit results on RMSEA and marginal fit results on Critical N and Goodness of Fit. Thus, it can be concluded that the overall fit of this model has met the requirements. Based on the previous description, can be seen from the following table and figure: 
Adi Yudi

Endang Ruswanti

Table 1.

Construct Reliability and Variance Extracted Calculation Results

\begin{tabular}{|c|c|c|c|c|c|c|c|c|c|}
\hline \multirow[t]{2}{*}{ Variable } & \multirow{2}{*}{$\begin{array}{l}\text { Standard } \\
\text { Loading }\end{array}$} & \multirow[t]{2}{*}{ Error } & \multicolumn{4}{|c|}{ Construct Reliability } & \multicolumn{3}{|c|}{ Variance Extracted } \\
\hline & & & $\sum_{\text {Loading }}$ STd. & $\begin{array}{l}\left(\sum \text { STd. }\right. \\
\text { Loading) }\end{array}$ & $\sum_{\text {Error }}$ & CR & $\begin{array}{l}\text { Standard } \\
\text { Loading }\end{array}$ & $\sum_{\text {Loading })^{2}}$ & VE \\
\hline \multicolumn{10}{|c|}{ Service Failure } \\
\hline SF1 & 0,93 & 0,13 & \multirow[t]{4}{*}{3,57} & \multirow[t]{4}{*}{12,74} & \multirow[t]{4}{*}{0,81} & \multirow[t]{4}{*}{0,94} & 0,86 & \multirow[t]{4}{*}{3,19} & \multirow[t]{4}{*}{$\mathbf{0 , 8 0}$} \\
\hline SF2 & 0,94 & 0,12 & & & & & 0,88 & & \\
\hline SF3 & 0,87 & 0,24 & & & & & 0,76 & & \\
\hline SF4 & 0,83 & 0,32 & & & & & 0,69 & & \\
\hline \multicolumn{10}{|c|}{ Service Recovery } \\
\hline SR1 & 0,87 & 0,25 & \multirow[t]{4}{*}{3,59} & \multirow[t]{4}{*}{12,89} & \multirow[t]{4}{*}{0,77} & \multirow[t]{4}{*}{$\mathbf{0 , 9 4}$} & 0,76 & \multirow[t]{4}{*}{3,23} & \multirow[t]{4}{*}{$\mathbf{0 , 8 1}$} \\
\hline SR2 & 0,93 & 0,14 & & & & & 0,86 & & \\
\hline SR3 & 0,93 & 0,13 & & & & & 0,86 & & \\
\hline SR4 & 0,86 & 0,25 & & & & & 0,74 & & \\
\hline \multicolumn{10}{|c|}{ Customer satisfaction } \\
\hline SC1 & 0,72 & 0,48 & \multirow[t]{6}{*}{4,92} & \multirow[t]{6}{*}{24,21} & \multirow[t]{6}{*}{2,11} & \multirow[t]{6}{*}{0,92} & 0,52 & \multirow[t]{6}{*}{4,05} & \multirow[t]{6}{*}{0,66} \\
\hline SC2 & 0,83 & 0,31 & & & & & 0,69 & & \\
\hline SC4 & 0,86 & 0,42 & & & & & 0,74 & & \\
\hline SC5 & 0,87 & 0,25 & & & & & 0,76 & & \\
\hline SC6 & 0,78 & 0,39 & & & & & 0,61 & & \\
\hline SC7 & 0,86 & 0,26 & & & & & 0,74 & & \\
\hline \multicolumn{10}{|c|}{ Customer Loyalty } \\
\hline LC1 & 0,86 & 0,25 & \multirow[t]{5}{*}{4,15} & \multirow[t]{5}{*}{17,22} & \multirow[t]{5}{*}{1,71} & \multirow[t]{5}{*}{0,91} & 0,74 & \multirow[t]{5}{*}{3,45} & 0,67 \\
\hline LC2 & 0,76 & 0,43 & & & & & 0,58 & & \\
\hline LC3 & 0,89 & 0,38 & & & & & 0,79 & & \\
\hline LC4 & 0,84 & 0,30 & & & & & 0,71 & & \\
\hline LC5 & 0,80 & 0,35 & & & & & 0,64 & & \\
\hline
\end{tabular}

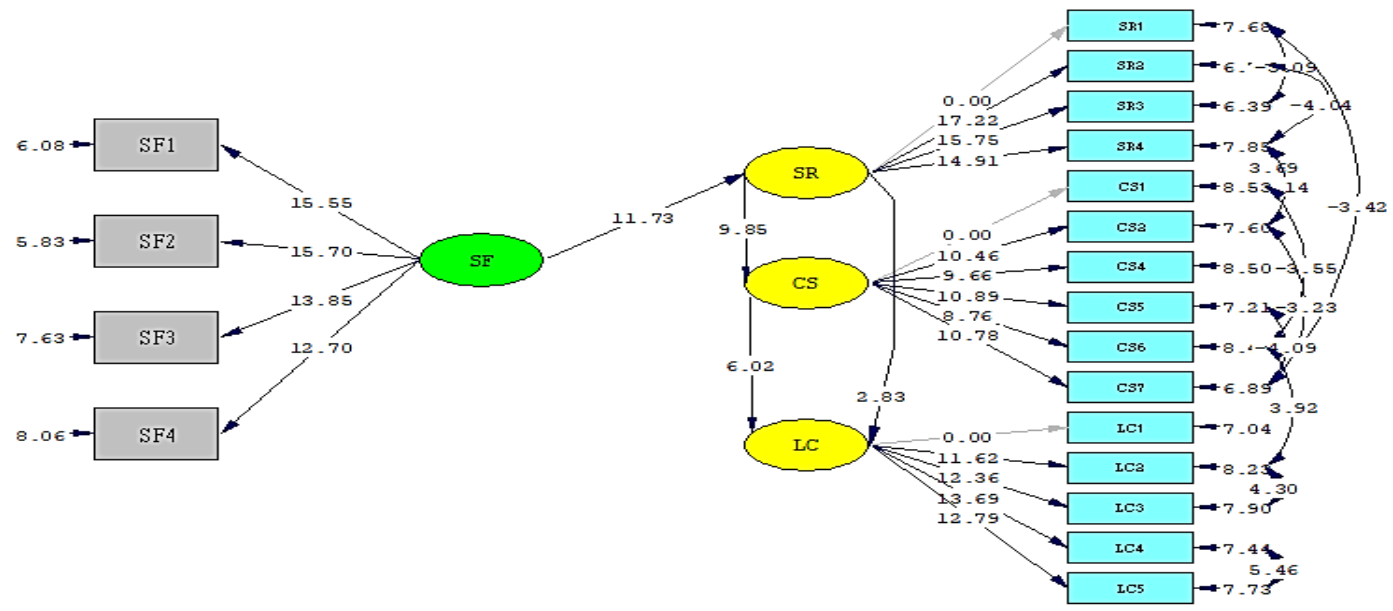

Chi-Square $=151.11, \mathrm{df}=137, \mathrm{P}-\mathrm{value}=0.19363, \mathrm{RMSEA}=0.025$

Figure 2. Path Diagram of T-Value 
Based on Figure 2, Path Diagram of T-Value, thus the hypothesis in this research can be seen in the table below:

Table 2.

Hypothesis Test for the Research Model

\begin{tabular}{llrll}
\hline Hypothesis & \multicolumn{1}{c}{ Hypothesis Statement } & $\begin{array}{r}\text { T-Value } \\
(>1,96)\end{array}$ & Description \\
\hline \multirow{2}{*}{ H1 } & $\begin{array}{l}\text { Service failure has a positive effect on service } \\
\text { recovery. }\end{array}$ & 11,73 & Significant \\
$\mathrm{H} 2$ & $\begin{array}{l}\text { Service recovery has an effect on customer loyalty. } \\
\mathrm{H} 3\end{array}$ & $\begin{array}{l}\text { Service recovery has an effect on Customer } \\
\text { Satisfaction. }\end{array}$ & 9,83 & Significant \\
$\mathrm{H} 4$ & $\begin{array}{l}\text { Customer satisfaction has an effect on customer } \\
\text { loyalty. }\end{array}$ & 6,02 & Signifificant \\
\hline
\end{tabular}

Source: SEM data processed using Lisrel

Based on the hypothesis test table above, it is known that all variables have a T-Value above 1.96. Thus, this research supports all the established research hypotheses.

\section{Discussion}

This study intends to exploit the influence and relationship of each variable between service failure, service recovery, customer satisfaction, and customer loyalty. In the test of the first hypothesis $(\mathrm{H1})$, it is found that service failure has an effect on service recovery in freight forwarding consumers. This means that service failure will be repaired by service recovery for the freight forwarding customers. Service recovery can occur from what has been done by service providers in response to service failures to customers (Weun, Beatty and Jones, 2004). The existence of service recovery is a process to return aggrieved customers to be more satisfied with the organization after the service or product failed (Stratemeyer et al., 2014). Service Recovery includes actions and activities that service providers adapt to "repair, modify, and recover from losses suffered" by the customer due to the service lack (Role et al., 2020). The results of this research support prior research from Ye and Luo (2016), which stated that service failure was found to affect service recovery positively.

This research has proven an effect from service recovery on customer loyalty in freight forwarding service consumers ( $\mathrm{H} 2)$. If complaints are not handled properly, it will result in consumer dissatisfaction, separation with the used service, and many consumers telling their disappointment to others. Thus the company will experience a loss of customers (Witt et al., 2008). Loyalty can refer to the passionate commitment held by customers to repurchase or repurchase a preferred product or service over and over again (Atuo and Kalu, 2017). Leow, 


\section{Adi Yudi \\ Endang Ruswanti}

(2015) also found that the service recovery process influenced customer satisfaction and customer loyalty with cases in the airline industry.

This research states that service recovery influences customer satisfaction in freight forwarding service consumers $(\mathrm{H} 3)$. If the complaints of problems from the customers have been handled, then the customer will be satisfied with the use of the freight forwarding service. Loureiro (2010) also found that service recovery has a positive effect on customer satisfaction. Improving conditions for service recovery will provide opportunities to increase customer satisfaction (Morrisson and Huppertz, 2010). Service recovery must have a strategy that is considered effective in restoring the company's image to restore customer trust so that customers become loyal returns (Miyonga, 2019). Customers will receive more benefits than they expect from service recovery, which will increase customer satisfaction (Kim et al., 2009).

Thus, customer satisfaction influences customer loyalty in freight forwarding service consumers $(\mathrm{H} 4)$. Customers who are satisfied with the treatment and services provided will become loyal customers to use the freight forwarding service. Customer satisfaction can provide benefits, including a more harmonious relationship between the service provider and customers, giving a good impression to consumers, and creating customer loyalty (Flint, Blocker and Boutin, 2011). The higher consumers' satisfaction and loyalty towards the company, the more competitive and profitable the company (Bian et al., 2019). This research results follow Ajami et al. (2018), which stated that customer loyalty had been found to have a positive impact.

\section{CONCLUSION}

This study's main purpose is to empirically analyze the effect of several variables from service failure to customer loyalty in shipping companies. The business strategy that has been formed in management activities is declared capable of retaining customers to continue using the expedition services. The main contribution of this research is to find out how far customers who feel disappointed from using expedition services can feel satisfied and loyal from the services and services that have been provided.

Based on the results of this study, it is concluded that service failure influences service recovery, which means that a failure in service can be repaired by service recovery as the responsibility that freight forwarding service consumers have experienced. Service recovery has a positive effect on customer loyalty. If a customer has been provided a service recovery, the customer can become loyal and continue using the freight forwarding service. In this case, the service recovery also has an effect on customer satisfaction. Customers who 


\section{Jurnal Manajemen Teori dan Terapan \\ Volume 14. No. 2, Agustus 2021}

have already experienced service recovery from the freight forwarding service will be more satisfied. Thus, customer satisfaction has a positive influence on customer loyalty. The satisfaction experience felt by customers when using freight forwarding service can make the customers repurchase at the company and might become loyal customers.

The implication of this research is expected to be useful for freight forwarding companies in Jakarta, which can be used as an illustration of a good service flow from the start of experiencing service failure that can be repaired by service recovery, which can make these customers satisfied and loyal to the freight forwarding service companies. The implication of this research for researchers is to add the price variable as moderation. The objective for the formation of this price is to find out whether it can increase the relationship between these variables or even reduce it.

The limitations of this research can be considered for further research. This research used a questionnaire as a measuring tool to save time and effort. However, this questionnaire has a limitation in providing questions. There is a possibility that the respondent did not answer the questionnaire in real terms and only answered by filling out the questionnaire based on the ideal conditions expected and not the actual conditions that occurred. In addition to that, there is a limitation in distributing questionnaires that were only conducted in Jakarta city. Further research can be carried out in different places with more respondents to improve the accuracy of the analysis data and add research variables as moderation, such as price, to obtain more robust data results and more various variables to study.

\section{REFERENCES}

Ajami, M.P., Elola, L.N. and Pastor, J. 2018. Validation and improvement of the European Customer Satisfaction Index for the Spanish wine sector. TQM Journal, 30(2): 133-152.

Anderson, E.W. and Sullivan, M.W. 1993. The Antecedents and Consequences of Customer Satisfaction for Firms. Marketing Science, 12(2): 125-143.

Atuo, E.C. and Kalu, S. 2017. Service Failure Recovery and Customer Loyalty: A Study of Airline Industry in Nigeria. International Journal of Marketing and Communication Studies, 2(2): 33-46.

Bian, L.K., Haque, A., Wok, S. and Tarofder, A.K. 2019. The effect of customer satisfaction on customer loyalty in the motor industry. Opcion, 35(Special Issue 21): 947-963.

Boo, H.V. 2017. Service Environment of Restaurants: Findings from the youth customers. Journal of ASIAN Behavioural Studies, 2(2): 67. 


\section{Adi Yudi}

\section{Endang Ruswanti}

Boshoff, C. 1997. An experimental study of service recovery options. International Journal of Service Industry Management, 8(2): 110-130.

Brenneman, W.A. 2005. Statistics for Research. Technometrics, 47(1): 100-100.

Cheng, T.C.E., Lai, L.C.F. and Yeung, A.C.L. 2008. The driving forces of customer loyalty: A study of internet service providers in Hong Kong. International Journal of e-Business Research, 4(4): 26-42.

Christina, C., Business, I., Study, M. and Business, F.O.F. 2019. the Effect of E-Service Quality and Service Quality of Gojek With the Mediating Role of Customer Satisfaction on Customer Loyalty. 13(1): 62-94.

Dawi, N.M., Jusoh, A., Streimikis, J. and Mardani, A. 2018. The influence of service quality on customer satisfaction and customer behavioral intentions by moderating role of switching barriers in satellite pay TV market. Economics and Sociology, 11 (4): 198-218.

DeWitt, T., Nguyen, D.T. and Marshall, R. 2008. Exploring customer loyalty following service recovery: The mediating effects of trust and emotions. Journal of Service Research, 10(3): 269-281.

Dong, B., Evans, K.R. and Zou, S. 2008. The effects of customer participation in co-created service recovery. Journal of the Academy of Marketing Science, 36(1): 123-137.

Fan, A., Mattila, A.S. and Zhao, X. 2015. How does social distance impact customers' complaint intentions? A cross-cultural examination. International Journal of Hospitality Management, 47: 35-42.

Flint, D.J., Blocker, C.P. and Boutin: J. 2011. Customer value anticipation, customer satisfaction and loyalty: An empirical examination. Industrial Marketing Management, 40(2): 219-230.

Johnston, R. 2007. With the Overall Service.

Kau, A.K. and Loh, E.W.Y. 2006. The effects of service recovery on consumer satisfaction: A comparison between complainants and non-complainants. Journal of Services Marketing, 20(2): 101-111.

Keiningham, T.L., Morgeson, F. V., Aksoy, L. and Williams, L. 2014. Service Failure Severity, Customer Satisfaction, and Market Share: An Examination of the Airline Industry. Journal of Service Research, 17(4): 415-431. 


\section{Jurnal Manajemen Teori dan Terapan \\ Volume 14. No. 2, Agustus 2021}

Kim, T. (Terry), Kim, W.G. and Kim, H.B. 2009. The effects of perceived justice on recovery satisfaction, trust, word-of-mouth, and revisit intention in upscale hotels. Tourism Management, 30(1): 51-62.

Lai, M.C. and Chou, F.S. 2015. The Relationships among Involvement Level, Service Failure, Service Recovery Disconfirmation and Customer Lifetime Valve. Journal of Economics, Business and Management, 3(4): 452-457.

Leow.S.C, 2015. Airline Service Failure and Recovery: A Conceptual and Empirical Analysis Sen Choon Leow Salford Business School University of Salford, Salford, UK Submitted in Partial Fulfilment of the Requirements of the Degree of Doctor of Philosophy, April , 2015.

Li-hua, Y. 2012. Customer satisfaction antecedents within service recovery context: Evidences from "Big 4" banks in China. Nankai Business Review International, 3(3): 284-301.

Liaw, Y.F., Kao, J.H., Piratvisuth, T., Chan, H.L.Y., Chien, R.N., Liu, C.J., Gane, E., Locarnini, S., Lim, S.G., Han, K.H., Amarapurkar, D., Cooksley, G., Jafri, W., Mohamed, R., Hou, J.L., Chuang, W.L., Lesmana, L.A., Sollano, J.D., Suh, D.J. and Omata, M. 2012. Erratum: AsianPacific consensus statement on the management of chronic hepatitis B: A 2012 update (Hepatology International (2012) 6 (531-561) DOI: 10.1007/s12072-012-9365-4). Hepatology International, 6(4): 809-810.

Lin, C.P. and Ding, C.G. 2007. Evaluating group differences in gender during the formation of relationship quality and loyalty in ISP service. End User Computing Challenges and Technologies: Emerging Tools and Applications: 238-258.

Loureiro, S.M.C. 2010. Satisfying and delighting the rural tourists. Journal of Travel and Tourism Marketing, 27(4): 396-408.

Matikiti, R., Mpinganjira, M. and Roberts-lombard, M. 2018. ANTECEDENTS AND OUTCOMES OF POSITIVE DISCONFIRMATION AFTER SERVICE FAILURE AND RECOVERY. 14(2): 43-58.

Miyonga, J.A. 2019. Effect of Strategic Management Practices on Customer Retention in Commercial Banks in Kenya. 7(3): 1-279.

Morrisson, O. and Huppertz, J.W. 2010. External equity, loyalty program membership, and service recovery. Journal of Services Marketing, 24(3): 244-254.

Nikbin, D., Ismail, I., Marimuthu, M. and Salarzehi, H. 2012. The Relationship of Service Failure Attributions, Service Recovery Justice and Recovery Satisfaction in the Context of Airlines. Scandinavian Journal of Hospitality and Tourism, 12(3): 232-254. 


\section{Adi Yudi}

\section{Endang Ruswanti}

Nurlitasari, L. and Syah, T.Y.R. 2016. Pengaruh Kualitas Layanan Terahadap Kepuasan Dan Loyalitas (Kasus: Rumah Sakit Medika Permata Hijau Jakarta Barat). Media Studi Ekonomi, 19 (1): 95-110.

Pai, C.H., Ko, K.M. and Santos, T. 2019. A study of the effect of service recovery on customer loyalty based on marketing word of mouth in tourism industry. Revista de Cercetare si Interventie Sociala, 64: 74-84.

Palich, L.E., Cardinal, L.B. and Miller, C.C. 2000. Curvilinearity in the diversificationperformance linkage: An examination of over three decades of research. Strategic Management Journal, 21 (2): 155-174.

Park, J. and Ha, S. 2016. Co-creation of service recovery: Utilitarian and hedonic value and post-recovery responses. Journal of Retailing and Consumer Services, 28: 310-316.

Pugh, S.D. 2001. Service with a smile: Emotional contagion in the service encounter. Academy of Management Journal, 44(5): 1018-1027.

Role, T.H.E., Perceived, O.F., With, J., Recovery, S., The, I.N., Between, R., Of, E., Employess, F., Of, C., Internet, E. and Case, C. 2020. THE ROLE OF PERCEIVED JUSTICE WITH SERVICE RECOVERY IN THE CUSTOMER SATISFACTION AFTER SERVICE RECOVERY ". 21 (5): 134-148.

Santos, J. and Boote, J. 2003. A theoretical exploration and model of consumer expectations, post-purchase affective states and affective behaviour. Journal of Consumer Behaviour, 3(2): 142-156.

Sarkar Sengupta, A., Balaji, M.S. and Krishnan, B.C. 2015. How customers cope with service failure? A study of brand reputation and customer satisfaction. Journal of Business Research, 68(3): 665-674.

Seon Hee, K. 2016. The Structural Relationship among Service Failure, Service Recovery, Emotional Reaction and Recovery Satisfaction in the Airline Service. Indian Journal of Science and Technology, 9(26).

Smith, A.K. and Bolton, R.N. 2002. The effect of customers' emotional responses to service failures on their recovery effort evaluations and satisfaction judgments. Journal of the Academy of Marketing Science, 30(1): 5-23.

Stratemeyer, A.W., Geringer, S.D. and Canton, A.C. 2014. An exploratory investigation of the effects of service failure and recovery efforts on customer satisfaction", American Journal of Management, Vol. 14 No. 3: 20-28. 14(1988): 20-28. 
Wallin Andreassen, T. 2000. Antecedents to satisfaction with service recovery. European Journal of Marketing, 34(1/2): 156-175.

Weun, S., Beatty, S.E. and Jones, M.A. 2004. The impact of service failure severity on service recovery evaluations andpost-recovery relationships. Journal of Services Marketing, 18(2): 133-146.

Ye, H. and Luo, Y. 2016. The Research on the Impact of Service Failure Severity on Customer Service Failure Attribution in the Network Shopping. Proceedings of the Wuhan International Conference on E-Business (WHICEB): 483-490. 